\title{
Assessment of agrolandscape on hydrological indexes
}

\author{
V. Belolipskiy, \\ doctor of agricultural sciences \\ Poluliah M. \\ National Scientific Center "Institute of Soil Science and Agrochemistry" named after O.N. \\ Sokolovsky
}

The purpose. Assessment of soil-water protection agrolandscape on hydrological indexes with adaptation of erosionpreventive arrangement in drainage area. Methods. Laboratory-field (takeoff of soil samples, their structurallyaggregation analysis, determination of the content of humus, moisture content, erosion-preventive sustainability), mathematicalstatistical (correlation, fractional error), simulation of agrolandscapes. Results. Operation of agrolandscapes is determined by hydrological parameters of soils and environment (firmness of build of soil, deposits, quotient of protectvie effect of woodland belts, agricultural background). The outline model of optimization of soil-water protection agrolandscape is developed with differentiation on natural-anthropogenous groups in view of deficiency of moisture (from 0,7 NV, \%). Conclusions. Assessment of agrolandscape can be conducted according to watering of soils. Complex empirical model of stores of general moisture $(\mathrm{mm})$ in soil for vegetation period of crops in view of influencing factors (rainfall amount $-61,4 \%$; firmness of build of soil $-17,1$; agricultural background 14,6 , quotient of protective effect of woodland belts $-4,2 \%$ ) is the basis of natural-anthropogenous group of agrolandscape.

Key words: agrolandscape, agricultural background, simulation, watering, optimization, factors, methods, quotient, deficiency.

Statement of the problem. The question of the existence of soil erosion in the steppe regions with different agro technical activities devoted to the work of M. Shykula [9]; A. G. Tarariko [4]; S. Y. Bulygin [2]; V. A. Belolipskiy [1], P.G. Chornogo [6]; N. In. Shevchenko [7], Nering [10]. However, when applied to eroded soils of measures for minimization of soil processing technologies, the emphasis is on the study of their efficiency [3], and studies the performance evaluation of soil science AL on hydrological indicators of accumulation and preservation of moisture in the catchment, in fact, not held. This is only possible with the rational organization of land-use area.

Management of hydrological regime of soils in the catchment must flow through his detail on phases (periods) organogenesis of agricultural crops in the soil system: soil $\rightarrow$ lamellibrachia $\rightarrow$ staterequired the ability of agricultural background.

The rational organization of land farms, in particular, beamed catchments and soil science techniques in combination with conservation orientation will ensure the development of anti-erosion stability, reduce soil erosion up to 1.5-2.0 t/ha and the absorption of $10-15 \mathrm{~mm}$ of runoff [1]. The yield of crops will increase by 4$5 \mathrm{C} / \mathrm{ha}$, sunflower - will consistently be kept at the level of $17-20 \mathrm{~kg} / \mathrm{ha}$ [5].

Purpose of research - evaluation of the functioning soil science AL according to the hydrological indices with the adaptation of anti-erosion development of the catchment.

The object of study - agricultural landscapes beamed catchment with different combination of agricultural background and the system of field protective forest stripe.

Materials and methods research. Geographically, the study on the local level is represented by an object beam "Stukalova" (Northern exposition of the slope). Studied the spatial structure of agricultural landscape in the catchment slope 2-4o to fallow, soil-protective forest belts (existing old and young, 2011) and 4-beam rotation (par-winter-legume-oilseed, sunflowerseed), the structure which defines the placement of the agricultural background in time and space with elements of AL. Soil - humus, heavy-loamy ordinary Chernozem on loess- like loam (Fig. 1). 


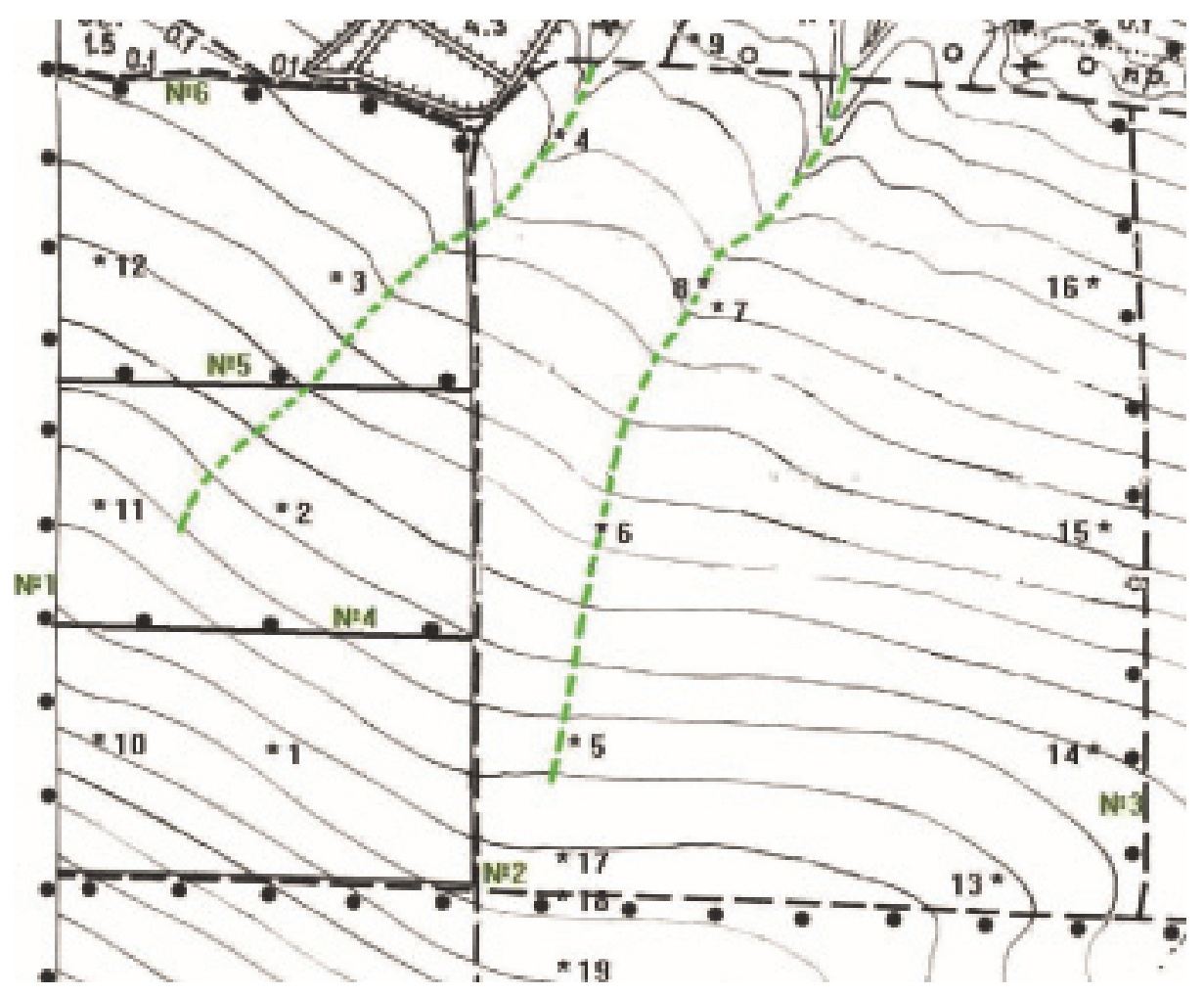

Fig. 1. The object of study is the catchment of the beam "Stukalova" (№1-3 - existing shelterbelts; No. 4-6 - shelterbelts 2011; * the point of observation)

Surveys, observations and analysis were conducted taking into account the following factors:

$\mathrm{X}_{1}$ - the quantity of precipitations, $\mathrm{mm}$ (local meteorological observations 2011-2013);

$\mathrm{X}_{2}$ - the average air temperature, $\stackrel{\stackrel{0}{C}}{\mathrm{C}}$ (Lugansk HMS data);

$\mathrm{X}_{3}$ - HTC Selyaninova (estimated):

$$
H T C=\frac{10 \sum H}{\sum_{t}}(1)
$$

where: $H$ - precipitation during the interval, $\mathrm{mm} ; \Sigma_{t}-$ the sum of active temperatures, ${ }^{\circ} \mathrm{C} ; \mathrm{X}_{4}-$ normalized precipitation for the cold period (estimated):

$$
H_{n}=\frac{\sum H_{\text {fact }}(\text { november }- \text { march })}{\sum H_{\text {mean }}(\text { november }- \text { march })}(2) \text {, }
$$

Where: $H_{\text {fact }}$ - actual precipitation, $H_{\text {mean }}$ - long-average precipitation, $\mathrm{mm}$;

$\mathrm{X}_{5}$ - humus content in the soil layer $0-20 \mathrm{~cm}, \%$ (agrochemical analysis of samples taken from designs for irrigation and underground mines);

$\mathrm{X}_{6}$ - coefficient soil erosion $C_{S e}$ (ranking the degree of erosion: erosion with the deposition of erosion products- 1,2 , weak erosion -1 , medium erosion - 0,9 , strong erosion $-0,8$ );

$\mathrm{X}_{7}$ - bulk density of soil layer $0-20 \mathrm{~cm}, \mathrm{~g} / \mathrm{cm}^{3}$ ( agro physical analysis of samples selected from the samples for spray irrigation and soil profiles);

$\mathrm{X}_{8}$ - profile height, $\mathrm{m}$ (map data);

$\mathrm{X}_{9}$ - coefficient of the protective action of forest belts (estimated):

$\mathrm{X}_{10}$ - agrobackground (adaptation for the simulation performed using the method of ranking coefficient according to the degree of moisture accumulation - moisture, discharge: fallow - 0,45 ; the forest $-0,50$; a sunflower for spring crops $-0,55$, sunflower in winter $-0,60$; legumes on corn and sunflower $-0,65$, legumes stubble $-0,70$; early spring for corn, sunflower $-0,75$, early spring on stubble $-0,80$; winter crops 
on stubble $-0,85$, winter steam $-0,90$; moldboard plowing $-0,95$; moldboard plowing of sunflower $-1,00$, moldboard plowing on winter $-1,05$; agro background with moisture saving measures $-1,1$ ).

$$
C_{\text {parp }}=\left(\frac{30 h_{1}}{l_{1}}+\frac{30 h_{2}}{l_{2}}+\frac{30 h_{n}}{l_{n}}\right)(3)
$$

Indicators of moisture:

1. Reserves total moisture $(\mathrm{mm})$ in the soil layer of $0-100 \mathrm{~cm}$ (thermostatic- weight method), vegetation period 2011-2013

2. Coefficient of soil moisture (calculated [8] by the formula):

$$
C_{m s}=\frac{W_{\text {prod }}}{0,7^{*} H B}(4)
$$

Where: Wprod - stocks productive moisture in one meter soil layer, $\mathrm{mm} H B$ - the lowest moisture capacity, mm (gradation HB for soils of different degrees of erosion: not erosion- 348, weak erosion - 334, medium erosion -320 , strong erosion -308 ),

3. The coefficient of productive moisture deficit (calculation formula):

$C_{p m d}=1-C_{m s}(5)$,

Where: $C_{m s}$ - coefficient of soil moisture Identifying impact factors of moisture accumulation of the agricultural landscape of the watershed of the beam, quantitative assessment of the residual method, which allows to identify the effect of each of them by constructing pairwise dependencies and the consistent exclusion of influence of each of $n$-variables [8].

The results of the research. The simulation of moisture reserves in the catchment of the agricultural landscape during the growing season to determine the effect of the studied factors $\left(X_{1}-X_{10}\right)$ on the stocks of productive moisture. Revealed that are triggered by such factors: rainfall, $\mathrm{mm}\left(\mathrm{X}_{1}\right)$, the coefficient of protective action of forest belts $\left(X_{9}\right)$, agro background $\left(X_{10}\right)$, bulk density of soil,

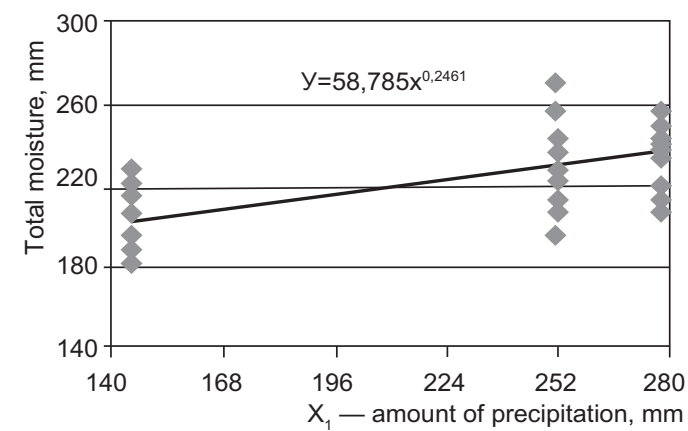

a

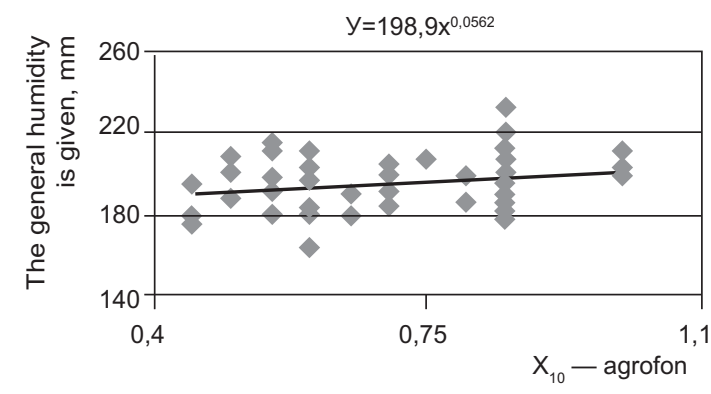

C

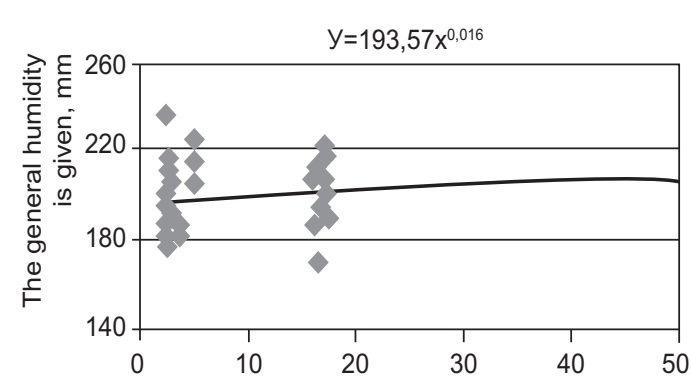

$X_{9}-$ coefficient of protective action of forest bands

b

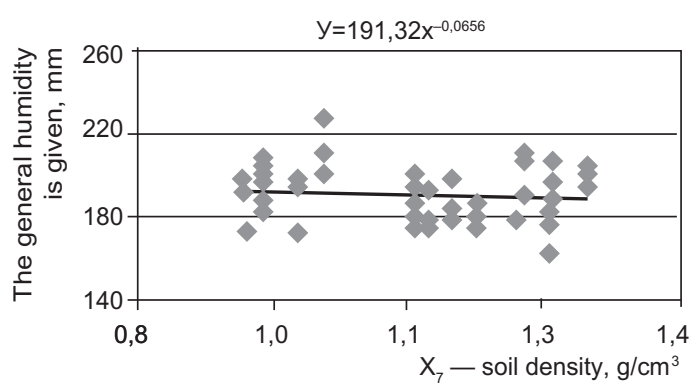

$d$

Fig. 2. The dependence of reserves total moisture (growing period) from:

A - rainfall, $\mathrm{mm} / \mathrm{min}\left(X_{1}\right), B$ - coefficient of the protective action of forest belts $(X 9)$, In - soil fertility (X10), G - density of the addition of soil, $\mathrm{g} / \mathrm{cm}^{3}(X 7)$.

A comprehensive empirical model of reserves total moisture $(\mathrm{mm})$ in the soil is expressed by the regression equation:

$$
\text { Ytotal }=A X_{1}{ }^{0,2461} X_{9}{ }^{0,016} X_{10}{ }^{0,0562} x_{7}-0,0656
$$


Where A - a constant factor equal to 54,44 .

The coefficient of multiple correlation -0.99 , relative error $-0,14 \%$. In providing moisture $A L$ greatest impact are:

1. The amount of precipitation (natural and) $-64,1 \%$ increases moisture ensuring.

2. The density of the soil (soil) - 17,1\% - decreases with increasing moisture availability of its value;

3. Agro background (anthropogenic) - 14,6\% - an increase in the margin provide moisture and mold from dumping cultivation, mulching and sunflower residues;

4. Coefficient protective effect of forests (anthropogenic) - 4,2\% - a slight increase in provision moisture caused by inadequate shelter forestation. Modeled overall performance of stocks listed in moisture soil moisture $\mathrm{g} / \mathrm{cm} 3\left(X_{7}\right)-($ Fig. 2$)$.

coefficient soil moisture $(\mathrm{Csm})$ and built a schematic model of soil water conservation agricultural landscapes, which defines the areas and terms Shuttle factors studied (Fig. 3).

Area increase the rate of hydration observed in the precipitation of $320 \mathrm{~mm}$ of rainfall during the growing period with a coefficient of protective action of shelterbelts $\geq 20$ cumulative and humid events.

Based on the index of moisture deficit KDPW (in the layer $0-100 \mathrm{~cm} 0.7 \mathrm{NV}-\%$ of productive moisture) natural and anthropogenic groups of the agricultural landscape (PKU compacted arable land, tilled crops in short crop rotations) offered differentiated activities (models) that correspond to a particular ecological situation (table. 1).

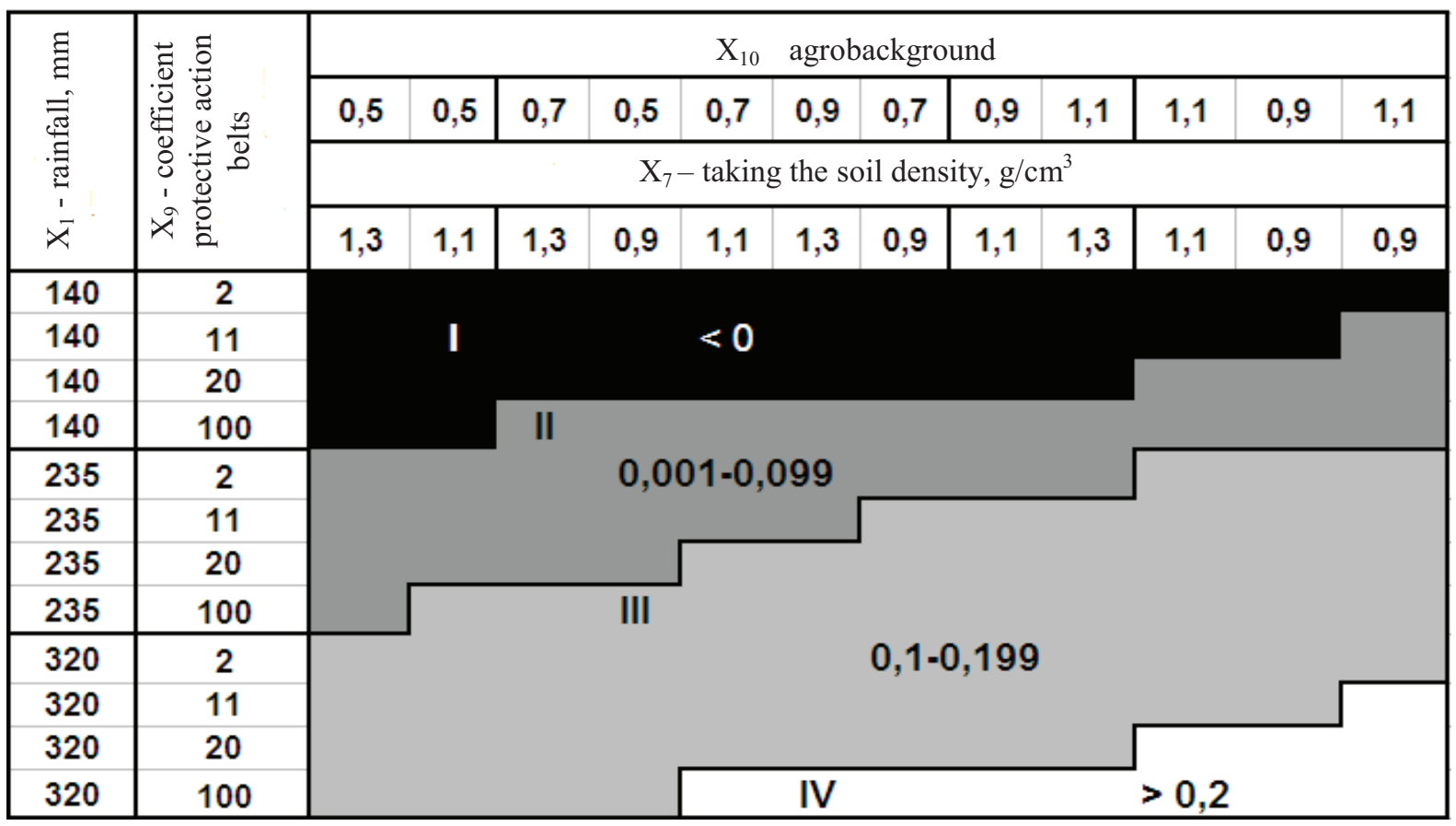

Fig. 3. Optimization of hydrological parameters of soils beamed catchment

1. Natural and anthropogenic groups of AL on the deficit of productive moisture of the soil.

\begin{tabular}{|l|l|l|}
\hline $\begin{array}{l}\text { Natural- } \\
\text { anthropogenic group }\end{array}$ & $\begin{array}{l}\text { Moisture deficit(0-100 cm Activities appropriate erosion and environmental situations } \\
\text { layer from } 0.7 \mathrm{HB} \% \\
\text { productive) }\end{array}$ & $\begin{array}{l}\text { Radical improvement of NGL with the measures for the } \\
\text { increase of moisture accumulation and the regulation of } \\
\text { the flow (periodic mechanical cutting slits across the slope, } \\
\text { etc.) }\end{array}$ \\
\hline $\begin{array}{l}\text { grasslands (NGL) } \\
\text { background with }- \text { Agro } \\
\text { surface treatment in } \\
\text { winter wheat, early }\end{array}$ & $\geq 90$ & $\begin{array}{l}\text { The improvement of erosive and hydrological arrangement } \\
\text { of } \\
\text { the } \mathrm{AL} \text { with a coefficient of protective action of forest } \\
\text { belts }>20, \text { water protection soil structure short-term crop }\end{array}$ \\
\hline
\end{tabular}




\begin{tabular}{|l|l|l|}
\hline $\begin{array}{l}\text { spring, sunflower with } \\
\text { the belts after } 500 \mathrm{~m} \\
\text { and more }\end{array}$ & $\begin{array}{l}\text { rotations: three field crop rotation with occupied fallow: } \\
\text { winter-33,7, sunflower } \\
16.8 \% \text { and fallow } 33,7 \%\end{array}$ \\
\hline $\begin{array}{l}3-\text { background corn } \\
\text { couple } \\
\text { with moldboard } \\
\text { plowing and forest } \\
\text { belts of } 500 \text { meters. }\end{array}$ & $\begin{array}{l}\text { Increase anti-erosion ability, softening the soil, reducing } \\
\text { loss of } \\
\text { flow system of fertilizers and vermicompost (soil } \\
\text { aggregation) }\end{array}$ \\
\hline $\begin{array}{l}4-\text { Short crop } \\
\text { rotation with } \\
\text { surface treatment and } \\
\text { the system of forest } \\
\text { belts after } \\
300 \mathrm{~m} .\end{array}$ & $\begin{array}{l}\text { Agrolandscapes soil has security orientation. Requires use } \\
\text { of area farming, strengthening forest belts moisture } \\
\text { accumulation and agronomic activities using the direct } \\
\text { seeding crops }\end{array}$ \\
\hline
\end{tabular}

Thus, according to the conceptual model soil science agro landscape optimization of the hydrological parameters of soils should be performed in the following directions:

1. The cumulative use of moisture proof and moisture saving agricultural technologies;

2. Unzip the humus and upper transition layer of eroded soils;

3. Improving soil protective effects of shelterbelts in the spatial organization of the catchment.

\section{Conclusions}

The functioning of the agro landscape on elevated catchment is characterized by a total moisture reserves during the growing season, S.-G. crops, which are estimated: Ytotal $=A^{*} X_{1}{ }^{0,2461} * X_{9}{ }^{0,016}$ * $x_{10} 0,0562 * x_{7}-0,0656$

Simulation results revealed the distribution of influence factors of moisture:

precipitation $-61,4 \%$; agro background of $14.6 \%$, the density of the soil is $17.1 \%$, the coefficient of protective action of forest belts was $4.2 \%$. The coefficient of multiple correlation of the model is 0.99 , relative error is $0.14 \%$.

Conceptual model of the functioning of the agricultural soil scince can be used for natural and manmade group of $\mathrm{AL}$ on the deficit of productive moisture $(0.7 \mathrm{HB})$ and development of differentiated activities (models) of management of hydrological regime for a particular environmental situations.

\section{Bibliography}

1. Belolipskiy V. O. Problemy gruntozakhysnoho obrobitku v ahrolandshaftakh Pivnichnoho Stepu/ V. O. Belolipskyi, Yu. I. Usatenko, A. M. Mytroshyn, V. I. Tarasov//Visnyk ah-rarnoi nauky. - 2008. - №7. S. 13-16.

2. Bulyhin S. lu. Formuvannia ekolohichno stalykh ahrolandshaftiv. Pidruch. Dlia pidhotovky spetsialistiv $\vee$ ahrar. vyshch. navch. zakladakh III-IV rivnia akredytatsii. - K.: Urozhai, 2005. - $300 \mathrm{~s}$.

3. Ryibina V.N. Effektivnost primeneniya biogumusa i mineralnyih udobreniy pri vyiraschivanii polevyih kultur/V.N. Ryibina , A.I. Denisenko, M.S. Chizhova, S.N. Nesterenko, V.S. Hashachih//Zb. nauk. prats Luganskogo NAU. - Lugansk: LNAU, 2009. - №100. - S. 133-136.

4. Tararyko O.H. Suchasna model gruntozakhysnoi systemy zemlerobstva z kon-turno-melioratyvnoiu orhanizatsiieiu terytorii//Grunty - osnova Kn. 1. - S. 181-183.

5. Tararyko O.H. Okhorona ta vidnovlennia dehradovanykh gruntiv vidpovidno proektu gruntovoi dyrektyvy Yevrosoiuzu/O.H. Tararyko, V.O. Hrekov, V.M. Panasenko//Visn. ahrar. nauky. - 2011. - №5. S. 9-13.

6. Chorniy S.H. Otsinka dopustymoi normy erozii dlia gruntiv Stepu Ukrainy/S.H. Chornyi//Ukrainskyi heohrafichnyi zhurnal. - 1999. - №4. - S.18-22. 
7. Shevchenko M.V. Systemy obrobitku gruntu/M.V. Shevchenko//Zemlerobst-vo. - Vyp. 80. -K.: VD "Ekmo", 2008. - S. 33-39.

8. Shelyakin N.M. Konturno-meliorativnoe zemledelie na sklonah/N.M. She- lyakin, V.A. Belolipskiy, I.N. Golovchenko - K.: Urozhay, 1990. - 168 s.

9. Shikula N.K., Nazarenko G.V. Minimalnaya obrabotka chernozemov i vosp- roizvodstvo ih plodorodiya. - M.: Agropromizdat, 1990. $-320 \mathrm{~s}$.

10. Nearing M.A., Foster R.G., Lanc L.J., Finkner S.C. A process - based soil erosion model for USDA - Water erosion prediction project technology. Trans ASAE. - V. 32(5), 1989. - p. 1587-1593. 